\title{
ANALISIS RASIO KEUANGAN UNTUK MENILAI KINERJA KEUANGAN PADA PT. ADIRA DINAMIKA MULTI FINANCE YANG TERDAFTAR DI BURSA EFEK INDONESIA
}

\author{
Andi Muhammad Hasbi Munarka ${ }^{1}$ \\ Sulastri Adeningsih²
}

No. HP $08124200669^{1}$

\begin{abstract}
ABSTRAK
Tujuan penelitian adalah untuk mengetahui perkembangan kinerja keuangan pada PT. Adira Multifinance Tbk. Berdasarkan data dari laporan keuangan pada tahun 2009 ,2010, 2011, dan 2012. Penelitian ini dilakukan pada lembaga yang berkaitan langsung dengan kegiatan pasar modal yaitu Pusat Informasi Pasar Modal (PIPM) yang merupakan kuasa Perwakilan Bursa Efek Indonesia dapat diakses melalui www.idx.co.id. Dengan waktu penelitian yaitu dimulai pada Bulan Desember tahun 2013 sampai dengan bulan Februari Tahun 2014. Metode analisis data yang digunakan didalam penelitian ini yaitu menggunakan rasio likuiditas, solvabilitas, dan provitabilitas.

Dari hasil analisis kinerja keuangan pada PT. Adira Dinamika Multi Finance Tbk dengan menggunakan penelitian Rasio Likuiditas posisi Likuiditasnya yang ditunjukkan oleh Current Ratio dan working Capital to Tottal Asset (WCTA) kurang sehat. Dari hasil analisis kinerja keuangan pada PT. Adira Dinamika Multi Finance Tbk dengan menggunakan penelitian Rasio Solvabilitas posisi likuiditas perusahaan yang ditunjukkan oleh Debt To Tottal Asset Ratio dan Debt To Tottal Equity Ratio kurang sehat. Dari hasil analisis kinerja keuangan pada PT. Adira Dinamika Multi Finance Tbk dengan menggunakan penelitian Rasio Profitabilitas posisi likuiditas perusahaan yang ditunjukkan oleh Return on Asset (ROA) dan Return on Equity (ROE) kurang sehat. Dari ketiga rasio untuk mengukur kinerja keuangan pada PT. Adira Dinamika Multi Finance Tbk, yaitu Rasio Likuiditas, Rasio Solvabilitas, dan Rasio Profitabilitas belum membuktikan hipotesis penelitian.
\end{abstract}

Kata kunci: Laporan Keuangan, Rasio Likuiditas, Rasio Solvabilitas, dan Rasio Profitabilitas.

\section{PENDAHULUAN}

Pada dasarnya setiap perusahaan selalu berusaha menjaga kelangsungan hidup usahnya. Terjaminnya kelangsungan hidup perusahaan terlihat apabila tujuan perusahaan dapat tercapa, yaitu meningkatkan profit sesuai dengan planning yang menunjang stabilitas usaha perusahaan, dan didukung oleh posisi keuangan perusahaan yang ada dalam keadaan yang seimbang.

Suatu perusahaan dikatakan kondisi keuangannya dalam keadaan seimbang apabila perusahaan tersebut dapat mebiayai aktivitas-aktivitas yang dijalankan dan tidak mengalami kesulitan dalam memenuhi kewajibannya pada pihak lain, baik jangka pendek maupun jangka panjang. Dalam hal ini peran manajemen keuangan perusahaan diperlukan untuk merencanakan secara tepat bagaimana cara pemenuhan, penggunaan, dan pengawasan alokasi dana. Hal ini termasuk dalam kegiatan pembelanjaan perusahaan. Perusahaan didirikan sebagai suatu organisasi yang dimanfaatkan untuk memenuhi kebutuhan manusia dan bertujuan 
untuk mendapatkan keuntungan yang maksimal. Agar tujuan yang akan dicapai dapat terwujud, maka diperlukan kebijaksanaan perusahaan yaitu perusahaan harus mempunyai manajemen yang baik. Ada beberapa teknik dalam menganalisis laporan keuangan salah satunya adalah dengan analisis rasio keuangan, diantaranya rasio likuiditas, rasio solvabilitas, dan rasio rentabilitas yang merupakan indikator dari analisis keuangan secara menyeluruh. Dengan mengetahui tingkat likuiditas, solvabilitas dan rentabilitas maka dapat menunjukkan kemampuan perusahaan dalam menghasilkan keuntungan serta mengetahui kemampuan perusahaan untuk dapat memenuhi kewajibanya, baik kewajiban jangka pendek maupun jangka panjang. PT. Adira Multi Finance Tbk. Terus berupaya memberikan pelayanan yang terbaik kepada masyarakat dalam hal penyediaan jasa pembiayaan. Semakin besarnya persaingan khususnya dalam bidang jasa pembiayaan mengakibatkan PT. Adira Multi Finance Tbk juga mendapat ancaman dalam kelangsungan operasinya. Adanya biayabiaya yang bersifat tetap yang harus dibayar baik ada maupun tidak ada operasi perusahaan serta kewajiban-kewajiban jangka pendek yang harus segera dilunasi terkadang menjadi masalah dikarenakan pendapatan yang kurang maksimal akibat dari pesatnya persaingan yang dihadapi. Dengan demikian tingkat likuiditas, solvabilitas maupun profitabilitas menjadi perhatian khusus pihak manajemen perusahaan agar PT. Adira Multi Finance Tbk dapat terus beroperasi.

\section{METODE PENELITIAN}

Penelitian ini dilakukan pada lembaga yang berkaitan langsung dengan kegiatan pasar modal yaitu Pusat Informasi Pasar Modal (PIPM) yang merupakan kuasa perwakilan Bursa Efek Indonesia dapat diakses melalui www.idx.co.id. Jenis dan sumber data yang digunakan yaitu Data Kuantitatif adalah data berupa angka-angka, seperti, neraca dan laporan laba rugi PT. Adira Multi Finance Tbk. yang diakses langsung melalui www.idx.co.id,

\section{Metode Pengumpulan Data}

Pengumpulan data dalam penelitian ini dilakukan dengan teknik sebagai berikut:

1. Pengamatan (observasi), yaitu teknik yang digunakan untuk mengumpulkan data pada PT. Adira Multi Finance Tbk dengan hanya mengamati, melihat tanpa melakukan wawancara atau mengajukan pertanyaan.

2. Dokumentasi, merupakan suatu metode pengumpulan data yang relevan dengan objek yang diteliti seperti hasil penelitian laporan keuangan industri yang diteliti dan buku-buku pedoman atau literature.

\section{HASIL PENELITIAN DAN PEMBAHASAN}

\section{Pembahasan Hasil Penelitian}

Adapun hasil rekapitulasi hasil perhitungan rasio likuiditas, rasio solvabilitas, dan rasio profitabilitas dapat di tunjukkan pada tabel berikut: 
Tabel 1

Rekapitulasi Hasil Perhitungan Rasio Likuiditas, Rasio Solvabilitas, dan Rasio Profitabilitas.

\begin{tabular}{|c|c|c|c|c|c|c|}
\hline \multirow{2}{*}{} & \multicolumn{2}{|c|}{ Rasio Likuiditas } & \multicolumn{2}{c|}{ Rasio Solvabilitas } & \multicolumn{2}{c|}{ Rasio Profitabilitas } \\
\cline { 2 - 7 } & $\begin{array}{c}\text { Current } \\
\text { Ratio }\end{array}$ & $\begin{array}{c}\text { Working Capital } \\
\text { Total Asset (WCTA) }\end{array}$ & $\begin{array}{c}\text { Debt to Total } \\
\text { Asset Ratio }\end{array}$ & $\begin{array}{c}\text { Debt to Total } \\
\text { Equity Ratio }\end{array}$ & ROE & ROA \\
\hline 2009 & $221 \%$ & $39,8 \%$ & $39 \%$ & $63 \%$ & $46 \%$ & $38 \%$ \\
\hline 2010 & $209 \%$ & $50,3 \%$ & $50 \%$ & $100 \%$ & $39 \%$ & $25 \%$ \\
\hline 2011 & $140 \%$ & $27,9 \%$ & $74 \%$ & $282 \%$ & $36 \%$ & $13 \%$ \\
\hline 2012 & $127 \%$ & $20,9 \%$ & $80 \%$ & $406 \%$ & $28 \%$ & $7 \%$ \\
\hline
\end{tabular}

Sumber: Data primer diolah, 2014

\section{Rasio Likuiditas}

\section{a. Current Ratio}

Dari hasil perhitungan pada laporan keuangan PT. Adira Multi Finance Tbk. untuk current ratio pada tabel diatas dapat dilihat bahwa pada tahun 2009 sampai dengan tahun 2012 nilai current ratio PT. Adira Multi Finance Tbk. mengalami penurunan. Hal ini disebabkan karena hutang lancar pada tahun 2009 sampai tahun 2012 mengalamai kenaikan.

\section{b. Working Capital to Asset (WCTA)}

Dari hasil perhitungan pada laporan keuangan PT. Adira Multi Finance Tbk. untuk rasio Working Capital to Asset (WCTA) pada tabel diatas dapat dilihat bahwa pada tahun 2009 sampai dengan tahun 2012 nilai Working Capital to Asset (WCTA) PT. Adira Multi Finance Tbk.

\section{Rasio Solvabilitas}

\section{a. Debt to Total Asset Ratio}

Dari hasil perhitungan pada laporan keuangan PT. Adira Multi Finance Tbk. untuk Debt to Total Asset Ratio pada tabel diatas dapat dilihat bahwa pada tahun 2009 sampai dengan tahun 2012 nilai Debt to Total Asset Ratio PT. Adira Multi Finance Tbk. mengalami kenaikan. Hal ini disebabkan karena total hutang pada tahun 2009 sampai tahun 2012 mengalamai kenaikan.

\section{b. Debt to Total Equity Ratio}

Dari hasil perhitungan pada laporan keuangan PT. Adira Multi Finance Tbk. untuk Debt to Total Equity Ratio pada tabel diatas dapat dilihat bahwa pada tahun 2009 sampai dengan tahun 2012 nilai Debt to Total Equity Ratio PT. Adira Multi Finance Tbk. mengalami kenaikan. Hal ini disebabkan 
karena total hutang pada tahun 2009 sampai tahun 2012 mengalamai kenaikan.

Dengan demikian dapat dikatakan bahwa kondisi PT. Adira Multi Finance. Tbk. dari Rasio Solvabilitasnya masih belum berjalan secara efisien. Artinya perusahaan belum mampu menggunakan total aktiva dan total ekuitasnya secara efektif untuk memenuhi kewajibannya.

\section{Rasio Profitabilitas}

\section{a. Return on Equity (ROE)}

Dari hasil perhitungan pada laporan keuangan PT. Adira Multi Finance Tbk. untuk Return on Equity (ROE) pada tabel diatas dapat dilihat bahwa pada tahun 2009 sampai dengan tahun 2012 nilai Return on Equity (ROE) PT. Adira Multi Finance Tbk. mengalami penurunan. Hal ini disebabkan karena kenaikan laba bersih pada tahun 2009 sampai tahun 2012 tidak lebih besar dari kenaikan modal.

\section{b. Return on Asset (ROA)}

Dari hasil perhitungan pada laporan keuangan PT. Adira Multi Finance Tbk. untuk Return on Asset (ROA) pada tabel diatas dapat dilihat bahwa pada tahun 2009 sampai dengan tahun 2012 nilai Return on Asset (ROA) PT. Adira Multi Finance Tbk. mengalami penurunan. Hal ini disebabkan karena kenaikan laba bersih pada tahun 2009 sampai tahun
2012 tidak lebih besar dari kenaikan total aktiva.

Dengan demikian dapat dikatakan bahwa kondisi PT. Adira Multi Finance. Tbk. dari Rasio Profitabilitasnya masih belum berjalan secara efisien. Artinya perusahaan belum mampu meningkatkan total aktiva dan total ekuitasnya secara efektif dalam menghasilkan laba.

Hasil penelitian ini sejalan dengan hasil penelitian yang dilakukan oleh Classyane dkk. 2012. Dengan judul penelitian "Analisis Laporan Keuangan Dalam Menilai Kinerja Keuangan Pada PT. Serba Mulia Auto Yamaha 3S Di Balikpapan. (Studi Kasus Pada PT. Serba Mulia Auto Yamaha 3S Di Balikpapan. Dimana hasil penlitian bahwa untuk rasio Profitabilitas mengalami penurunan untuk tiap tahunnya yaitu dari tahun 2010 sampai tahun 2011.

Kemudian penelitian yang dilakukan oleh Nilasari (2008). Dengan judul Analisis Rasio Keuangan Sebagai Alat Penilaian Untuk Mengukur Kinerja Keuangan Pada PT. Unilever Indonesia Tbk. Periode 2002-2007 (Studi Pada Pojok Bursa Efek Indonesia UMM). Dimana hasil penelitian sejalan dengan hasil penelitian ini. Dengan hasil penelitian yaitu secara keseluruhan keadaan profitabilitas perusahaan dari tahun 2002 sampai dengan tahun 2007 menunjukkan tingkat rasio yang 
berfluktuasi atau tidak menentu dari tahun ke tahun (tidak stabil).

\section{SIMPULAN}

Berdasarkan uraian - uraian pada hasil penelitian dan pembahasan maka peneliti dapat menarik kesimpulan sebagai berikut:

Dari hasil analisis kinerja keuangan pada PT. Adira Dinamika Multi Finance Tbk dengan menggunakan penilaian Rasio Likuiditas posisi likuiditasnya yang ditunjukkan oleh Current Ratio dan Working Capital to Total Asset (WCTA) kurang sehat

1. Dari hasil analisis kinerja keuangan pada PT. Adira Dinamika Multi Finance Tbk dengan menggunakan penilaian Rasio Solvabilitas posisi likuiditas perusahaan yang ditunjukkan oleh Debt To Total Asset Ratio dan Debt To Total Equity Ratio kurang sehat.

2. Dari hasil analisis kinerja keuangan pada PT. Adira Dinamika Multi Finance Tbk dengan menggunakan penilaian Rasio Profitabilitas posisi likuiditas perusahaan yang ditunjukkan oleh Return on Asset (ROA) dan Return on Equity (ROE) kurang sehat.

\section{SARAN}

Berdasarkan hasil pembahasan dan kesimpulan yang dperoleh dalam penelitian ini, maka dapat diberikan saran sebagai berikut:
1. PT. Adira Dinamika Multi Finance Tbk hendaknya terus memperhatikan kenaikan jumlah aktiva lancar yang dimiliki sebelum menambah jumlah hutang. Dengan menambah jumlah utang tanpa memperhitungkan jumlah aktiva lancar yang ada, tidak menutup kemungkinan perusahaan akan mengalami kesulitan dalam memenuhi kewajibankewajibannya.

2. Perusahaan sebaiknya mengurangi pinjaman dana dari pihak lain, karena semakin tinggi hutang perusahaan, maka resiko kebangkrutan perusahaan juga semakin tinggi.

\section{DAFTAR PUSTAKA}

Agnes Sawir. 2001. Analisis Kinerja Keuangan dan Perencanaan Keuangan Perusahaan. Jakarta: PT Gramedia Pustaka Utama.

Amin Wijaya Tunggal. (1995). Dasar Dasar Analisis Laporan Keuangan. Jakarta: Rineka Cipta.

Ang, Robert (1997), Buku Pintar Pasar Modal Indonesia, Jakarta, Mediasoft Indonesia.

Astuti, Dewi. 2004. Manajemen keuangan perusahaan. Cetakan pertama, Ghalia Indonesia, Jakarta.

Ikatan Akuntan Indonesia . 2007. Standar Akuntansi Keuangan . Edisi 2007. Penerbit : Salemba Empat . Jakarta

Irawati susan, (2006:25). Analisis Keuangan Perusahaan. Bandun: Alfabeta.

Mamduh Hanafi. (2004). "Manajemen Keuangan", BPFE, Yogyakarta. 
Martono. 2005. Manajemen Keuangan. Ekonisia: Jakarta.

Munawir. S. 2002. Analisis Informasi Keuangan. Yogyakarta. Liberty Yogyakarta

Nilasari, Fita. 2008. Analisis Rasio Keuangan Sebagai Alat Penilaian Untuk Mengukur Kinerja Keuangan Pada PT. Unilever Indonesia Tbk. Periode 20022007 (Studi Pada Pojok Bursa Efek Indonesia UMM). Skripsi. Fakultas Ekonomi. Universitas Islam Negeri (UIN) Malang.

Sucipto.2003."Penilaian Kinerja Keuangan" Digitized by USU digital library

www.IDX.co.id 